\title{
STUDI KOMPARATIF KEMAMPUAN MANAJERIAL KEPALA SEKOLAH PNS DAN PERSYARIKATAN DI SMP MUHAMMADIYAH KASIHAN DAN SMP MUHAMMADIYAH PUNDONG
}

\author{
Sigit Hadriyanto \\ Program Pasca Sarjana \\ Universitas Muhammadiyah Yogyakarta \\ E-mail: omgit@ymail.com
}

\begin{abstract}
Abstrak
Penelitian ini bertujuan untuk: (1) Menemukan signifikansi perbedaan kemampuan manajerial Kepala sekolah SMP Muhammadiyah Kasihan yang PNS Dan SMP Muhammadiyah Pundong yang Persyarikatan. (2) Menemukan faktor pembeda kemampuan manajerial Kepala sekolah SMP Muhammadiyah Kasihan dan Kepala sekolah SMP Muhammadiyah Pundong. Penelitian ini adalah penelitian lapangan menggunakan pendekatan kualitatif dengan metode deskriptif yang dilakukan di SMP Muhammadiyah Kasihan Bantul dan SMP Muhammadiyah Pundong Bantul DIY. Tehnik pengumpulan data, penulis menggunakan observasi, wawancara mendalam, dokumentasi. Hasil penelitian dan pembahsan menunjukkan bahwa: (1) Manajerial Kepala sekolah persyarikatan menurut hasil penelitian penulis dalam hal perencanaan lebih berani melakukan inovasi atau variatif artinya berani keluar dari nomenklatur kementrian pendidikan.. (2) Manajerial Kepala sekolah PNS menurut hasil penelitian penulis dalam hal perencanaan belum berani melakukan inovasi atau variatif artinya cenderung mengikuti nomenklatur kementrian pendidikan. Monitoring dan evaluasi dilakukan tetapai kurang transparan artinya tidak setiap warga sekolah tau tentang pelaporan sekolah.
\end{abstract}

Kata kunci: manajerial, kepala sekolah pns, persyarikatan.

\begin{abstract}
This study aims to: (1) Find the significance of differences in managerial ability of the Headmaster of Muhammadiyah Kasihan Middle School who are PNS and Persyarikatan Muhammadiyah Middle School. (2) Find the distinguishing factors of managerial ability of the Head of Muhammadiyah Kasihan Middle School and the Principal of Muhammadiyah Pundong Middle School. This research is a field research using a qualitative approach with descriptive methods conducted at the Muhammadiyah Middle School in Kasihan Bantul and the Muhammadiyah Middle School in Pundong, Bantul DIY. Data collection techniques, the authors use observation, in-depth interviews, documentation. The results of the study and discussion showed that: (1) Managerial Head of the school according to the author's research results in terms of planning more daring to innovate or varied means to dare to leave the nomenclature of the ministry of education. not daring to innovate or be varied means it tends to follow the nomenclature of the ministry of education. Monitoring and evaluation is done but is not transparent meaning that not every school citizen knows about school reporting.
\end{abstract}

Keywords: managerial, civil servants, principals.

\section{Info Artikel}

Diterima Januari 2020, disetujui Februari 2020, diterbitkan Juni 2020 


\section{PENDAHULUAN}

Pendidikan merupakan bagian terpenting disetiap negara termasuk di Indonesia. Salah satu permasalahan pendidikan yang dihadapi oleh bangsa Indonesia adalah masih rendahnya mutu pendidikan disetiap jenjang dan satuan pendidikan terutama dibagian dasar dan menengah. Rendahnya kemampuan manajerial Kepala sekolah menjadi salah satu penyebab tidak mutunya sekolah-sekolah Muhammadiyah. Di kabupaten Bantul terdapat 20 SMP Muhammadiyah yang Kepala sekolahnya 13 PNS dan 7 yayasan / persyarikatan.

Dari 20 SMP Muhammadiyah di kabupaten Bantul belum ada satu sekolahpun yang bisa dikatakan berkualitas. Hal ini ditunjukkan dari minimnya prestasi sekolah SMP Muhammadiyah baik ditingkat kabupaten, propinsi ataupun nasional, baik diinternal Muhammadiyah maupun bergabung dengan sekolah negeri. Yang dimaksud dengan prestasi adalah prestasi akademik dan non akademik. Prestasi akademik biasanya dilihat dari nilai Ujian Nasional / UN, dimana sekolah SMP Muhammadiyah jarang masuk 10 besar ditingkat kabupaten apalagi propinsi. Sedangkan prestasi non akademik biasanya diukur dari berbagai macam perlombaan ekstrakurikuler, hal ini pun sekolah SMP Muhammadiyah jarang berprestasi.

Diantara beberapa SMP Muhammadiyah di kabupaten Bantul penulis akan meneliti manajerial SMP Muhammadiyah Kasihan yang dipimpin oleh Kepala sekolah PNS dan manajerial SMP Muhammadiyah Pundong yang dipimpin oleh kepala sekolah persyarikatan. Dua sekolah ini penulis pandang sudah cukup mewakili kepala sekolah SMP Muhammadiyah sebantul. Dalam pengamatan penulis di dua sekolah tersebut terdapat perbedaak manajerial kepala sekolah yang membuat penulis tertarik untuk menelitinya.

Muhammadiyah yang terkenal memiliki amal usaha dibidang pendidikan sudah teruji dan terbukti kontribusinya terhadap kemajuan bangsa, akan tetapi seiring dengan perkembangan zaman dan pengaruh perkembangan tehnologi infomasi ( TI ) dan juga masyarakat ekonomi asia ( MEA ), amal usaha Muhammadiyah terutama pendidikan harus segera menyesuaikan diri dan harus bisa menjawab tatangan jaman yang berubah dengan cepat. Pengelolaan sekolah dan madrasah memerlukan suatu pola pengelolaan yang konsisten dengan visi, misi, tujuan serta kaidah dan pedoman pendidikan Muhammadiyah, serta kebijakan persyarikatan maupun Majelis Dikdasmen. 
Untuk mewujudkan tata kelola sekolah dan madrasah yang baik mensyaratkan Kepala sekolah madrasah dan sekolah Muhammadiyah memiliki kualifikasi dan kompetansi berikut:
a. Keislaman
b. Kepribadian
c. Kemuhammadiyahan
d. Manajerial
e. Kewirausahaan-sosial
f. Sosial dan kerjasama.

\section{METODE PENELITIAN}

Jenis penelitian adalah penelitian lapangan menggunakan pendekatan kualitatif dengan metode deskriptif, yang akan dilaksanakan di SMP Muhammadiyah Kasihan Bantul dan SMP Muhammadiyah Pundong Bantul. Dalam mengkaji masalah yang diangkat penulis berusaha mencari data primer maupun data sekunder dari sekolah yang diteliti. Penelitian kualitatif menurut Sugiono menyatakan bahwa ( qualitative research ) berasal dari filsafat kontruktivisme yang beranggapan bahwa realitas itu berdimensi jamak, interaktif dan suatu pertukaran pengalaman social (a share social experience ) yang di interpretesikan oleh individu-individu. Hal ini sesuai dengan pendapat dari Robert E. Stake yang menyatakan For Qualitative reseach, as indicatied earlier, the research him-or herself is an instrument, observing action and contexts, often intentionally playing a subjective role in the study, using his or her own personel experience in making interpretation.24 Dalam penelitian ini menggunakan Jenis penelitian kualitatif deskriptif yaitu proses penelitian yang menghasilkan data diskriptif berupa kata-kata yang tertulis atau lisan dari orang-orang dan perilaku yang dapat diamati. Penelitian diskriptif kualitatif adalah datanya bersifat kualitatif artinya data yang diujudkan dalam kata keadaan atau kata sifat. Penelitian deskriptif adalah suatu penelitian yang didalamnya meneliti status kelompok manusia, suatu obyek, suatu sistem pemikiran atau peristiwa dimasa sekarang.

Jadi dalam penelitian ini penulis menggambarkan serta mengeksplorasi bagaimana menajerial Kepala sekolah SMP Muhammadiyah Kasihan dan manajerial Kepala sekolah SMP Muhammadiyah Pundong secara langsung dari lapangan. 
Disamping itu juga penulis akan sampaikan perbedaan kemampuan manajerial dikedua sekolah tersebut. Termasuk faktor-faktor yang mempengaruhinya. Lebih lanjut peneliti harus mengumpulkan data secara menyeluruh yang dibatasi oleh waktu, dengan menggunakan teknik pengumpulan data.

\section{HASIL DAN PEMBAHASAN}

Hasil penelitian dan pembehasan terhadap kemampuan manajerial dua Kepala sekolah baik yang bersetatus PNS maupun persyaikatan mempunyai perbedaan adan persamaanya.

Tabel 1 .

Perbedaan Kepala Sekolah Persyarikatan dan PNS

\begin{tabular}{|l|l|l|}
\hline Unsur Manajerial & Kepala sekolah persyarikatan & Kepala sekolah PNS \\
\hline Perencanaan / Planning & Lebih berani berinovasi & $\begin{array}{l}\text { Sesuai nomenklatur } \\
\text { dinas }\end{array}$ \\
\hline $\begin{array}{l}\text { Pengorganisasian } \\
\text { Organizing }\end{array}$ & $\begin{array}{l}\text { Seluruh stake holder dilibatkan } \\
\text { dalam setiap program sekolah }\end{array}$ & $\begin{array}{l}\text { Tidak semua stake } \\
\text { holder dilibatkan dalam } \\
\text { setiap program sekolah } \\
\text { (terbatas ) }\end{array}$ \\
\hline Pelaksanaan / Actuating & $\begin{array}{l}\text { Tim bekerja secara total untuk } \\
\text { mencapai tujuan dalam setiap } \\
\text { kegiatan }\end{array}$ & $\begin{array}{l}\text { Tim belum bekerja } \\
\text { secara total untuk } \\
\text { mencapai tujuan dalam } \\
\text { setiap kegiatan }\end{array}$ \\
\hline Kontrol / Controlling & Lebih transparan & Kurang transparan \\
\hline
\end{tabular}

Tabel 2.

Persamaan Kepala Sekolah Persyarikatan dan PNS

\begin{tabular}{|l|l|l|}
\hline Unsur Manajerial & Kepala sekolah persyarikatan & Kepala sekolah PNS \\
\hline Perencanaan / Planning & $\begin{array}{l}\text { Menggunakan prinsip-prinsip } \\
\text { musyawarah }\end{array}$ & $\begin{array}{l}\text { Menggunakan prinsip- } \\
\text { prinsip musyawarah }\end{array}$ \\
\hline $\begin{array}{l}\text { Pengorganisasian } \\
\text { Organizing }\end{array}$ & $\begin{array}{l}\text { Berusaha mencari jaringan } \\
\text { sebanyak mungkin }\end{array}$ & $\begin{array}{l}\text { Berusaha mencari } \\
\text { jaringan rebanyak }\end{array}$ \\
\hline
\end{tabular}




\begin{tabular}{|c|c|c|}
\hline & & mungkin \\
\hline Pelaksanaan / Actuating & $\begin{array}{l}\text { Berusaha maksimal dalam } \\
\text { mencapai tujuan dalam setiap } \\
\text { program / kegiatan }\end{array}$ & $\begin{array}{l}\text { Berusaha maksimal } \\
\text { dalam mencapai tujuan } \\
\text { dalam setiap program / } \\
\text { kegiatan }\end{array}$ \\
\hline Kontrol / Controlling & $\begin{array}{l}\text { Melaksanakan monitoring dan } \\
\text { evaluasi }\end{array}$ & $\begin{array}{l}\text { Melaksanakan } \\
\text { monitoring dan } \\
\text { evaluasi }\end{array}$ \\
\hline
\end{tabular}

\section{KESIMPULAN}

Studi komperatif kemampuan manajerial kepala sekolah yang PNS dan ber SK Bupati dengan Kepala sekolah persyarikatan menurut hasil penelitian penulis, diantara kedua Kepala sekolah mempunyai persamaan dan perbedaan.

Manajerial Kepala sekolah persyarikatan menurut hasil penelitian penulis dalam hal perencanaan lebih berani melakukan inovasi atau variatif artinya berani keluar dari nomenklatur kementrian pendidikan. Dari segi pengorganisasianya mampu melibatkan seluruh Stake holder yang dibutuhkan dalam setiap program. Dari segi pelaksanaanya berusaha untuk total melaksanakan tugas/ kegiatan walau kadang hasilnya tidak sesuai dengan yang diharapkan. Monitoring dan evaluasi dilakukan secara terbuka dan transparan sehingga tidak ada kecurigaan terkait pelaporan kegiatan.

Manajerial Kepala sekolah PNS menurut hasil penelitian penulis dalam hal perencanaan belum berani melakukan inovasi atau variatif artinya cenderung mengikuti nomenklatur kementrian pendidikan. Dari segi pengorganisasianya belum mampu melibatkan seluruh Stake holder yang dibutuhkan dalam setiap program. Dari segi pelaksanaanya semangat atau ghiroh dalam melaksanakan tugas/ kegiatan belum bisa maksimal. Monitoring dan evaluasi dilakukan tetapai kurang transparan artinya tidak setiap warga sekolah tau tentang pelaporan sekolah.

Adapun faktor-faktor yang mempengaruhi kemampuan manajerial kepala sekolah, sesuai dengan penelitian yang penulis lakukan diantaranya adalah:

a. Kurangnya pengetahuan kepala sekolah terkait dengan teori-teori manajerial kepala sekolah. 
b. Prinsip manajerial dalam hal ini Planning, Organizing, Actuating dan Controlling belum dilakukan sebagaimana mestinya

c. Kurangnya komitmen bermuhammadiyah

\section{DAFTAR PUSTAKA}

Arikunto, S. 2010. Prosedur Penelitian Suatu Pendekatan Praktek. Jakarta: Rineka Cipta.

Bungin, B. 2005. Analisis Data Penelitian Kualitatif. Jakarta: PT Raja Grasindo Persada.

Creswell, J. 2015. Riset Pendidikan. Yogyakarta: Pustaka Pelajar.

Hadi, S. 2000. Metodologi Penelitian Research. Yogyakarta: Andi.

Hadis, A., dan Nurhayati. 2012. Manajemen Mutu Pendidikan. Bandung: Alfabeta.

Kholil, S. 2006. Metodologi Penelitian Komunikasi. Bandung: Cita Pustaka Media.

Kurnianto, H. 2015. Manajemen Sumber Daya Manusia. Yogyakarta: Visi Solusi Madani.

Kusumah, M. D. 2015. Pengaruh Motivasi Kerja dan Pelatihan Terhadap Kinerja Kepala Sekolah Di SDN Kabupaten Garut. Jurnal Admimistrasi Pendidikan. Universitas Pendidikan Indonesia.

Maisyaroh. 2010. Membangun Budaya dan Iklim sekolah di Era Global. Tesis. Universitas Negeri Malang.

Moleong, L. J. 2014. Metodologi Penelitian Kualitatif. Bandung: PT Remaja Rosda Karya.

Nazir, M. 2003. Metodologi Penelitian. Jakarta: PT Ghalia Indonesia.

Pidarta. 1998. Manajemen Pendidikan dalam Era Globalisasi. Jurnal Imu Pendidikan Universitas Negeri Malang.

Ridwan. 2004. Metode Riset. Jakarta: Rineka Cipta .

Robandi, I,. dan Hamami, T. 2011. The Creating of Great School. Yogyakarta: Majelis Pendidikan Dasar dan Menengah Pimpinan Wilayah Muhammadiyah Daerah Istimewa Yogyakarta.

Riyanto, Y. 2008. Metodologi Penelitian Kualitatif dan Kuantitatif. Surabaya: Unisa Press. 
Sanjaya, W. 2010. Penelitian Tindakan Kelas. Jakarta: Kencana Prenada Media Group.

Satori, D. K. A. 2010. Metode Penelitian Kualitatif. Bandung: Alfabeta

Sukmadinata, N. S. 2013. Metodologi Penelitian Pendidikan. Bandung: PT Remaja Rosdakarya.

Surana, M. R. 2010. Hubungan Antara Kemampuan Manajerial Kepala Sekolah, Motivasi Guru, Lingkungan Kerja Dan Komitmen Guru Dengan Kinerja Guru SMP Di Kabupaten Bantul. Tesis. Universitas Negeri Yogyakarta.

Tanzeh, A. 2009. Pengantar Metode Penelitian. Yogyakarta: Teras. 